\title{
過酸化水素を用いるハロゲンフリーエポキシ化 Hydrogen Peroxide Epoxidation under Halide-free Conditions
}

\author{
今 喜裕*・佐藤 一彦* \\ Yoshihiro KON and Kazuhiko SATO
}

\section{1.はじめに}

エポキシ樹脂は，二液性接着剤や，加熱して硬化させる 一液型接着剂として幅広く利用されている。近年では，優 れた接着性に加え，バランスのとれた接着性む示すエポキ シ樹脂接着剤が次々と開発されており, 従来用途（包装, ラベル，建材）に加えて，先端材料製造（ディスクやセン サーなど）にも適用範囲を広げている。特に，封止材など 光学用途に使用されるエポキシ樹脂は, 高い絶縁性能, 而讨 光性, および而湿性など様々な機能が要求される11。さら に近年では, 環境に配慮した持続的社会への関心が高まり, 欧米を中心に八ロゲンフリーなエポキシ樹脂を求める動き がでてきた 2 。このような事情から本稿ではエポキシ樹脂 製造に利用できる有用な方法として，八ロゲンを含む化合 物を一切使用しない反応条件でありながら，炭素一炭素二 重結合（オレフィン）からエポキシ化合物を高勃率に合成 可能な過酸化水素酸化反応について紹介する ${ }^{3)}$ 。また，実 用的な過酸化水素によるエポキシ化合物製造技術により塩 素フリーな封止材原料を製造した例も示す。

\section{2. ハロゲンフリーについて}

八ロゲンは周期表で 17 族に属する元素のことであり， フッ菜, 塩素, 臭素, ヨウ素, アスタチンを指す。八ロゲ ンを含むプラスチック製品を焼却することでダイオキシン や塩素ガスが発生するとの懸念から，欧州やアメリカでは 電子機器関連の学協会を中心にハロゲンフリーを規定して (る2,4)。日本であ，電子情報技術産業協会（JEITA）が 八ロゲンフリーの規格を提案しておうり, その中で, 八ロゲ ンフリーとしてみなせる塩素や臭素の製品中に混入して良

* (独) 産業技術総合研究所 触媒化学融合研究セン夕ー 茨城県つくば市東 1-1-1 つくば中央第五. National Institute of Advanced Industrial Science and Technology (AIST)

Central 5 Higashi 1-1-1, Tsukuba 305-8565, Japan
い下限値については, 塩素含有率 $900 \mathrm{ppm}$ 以下, 臭素含 有率 $900 \mathrm{ppm}$ 以下，としている5)。実際に光学材料用途の エポキシ化合物の場合, 芳香族グリシジルエーテル系で塩 素含有率数十 $\mathrm{ppm}$, 脂肪族グリシジルエーテル系で塩素 含有率数百 $\mathrm{ppm}$ 程度までハロゲン量が低隇された製品が 增えてきている4)。

\section{3. 過酸化水素を用いるエポキシ化合物の製造方法}

\section{1 従来法と過酸化水素酸化法}

従来，酸化反応によるエポキシ化合物の合成に使用され る有機過酸は, 反応後に酢酸などのカルボン酸を廃棄物と して副生し，その処理には大量の有機溶㓮，エネルギーを 使用する。また，現在工業的に最も頻繁に用いられている エピクロルヒドリン法（スキーム 1) は, 酸化反応ではな いが，エポキシ基を主骨格に導入できる極めて有用な方法

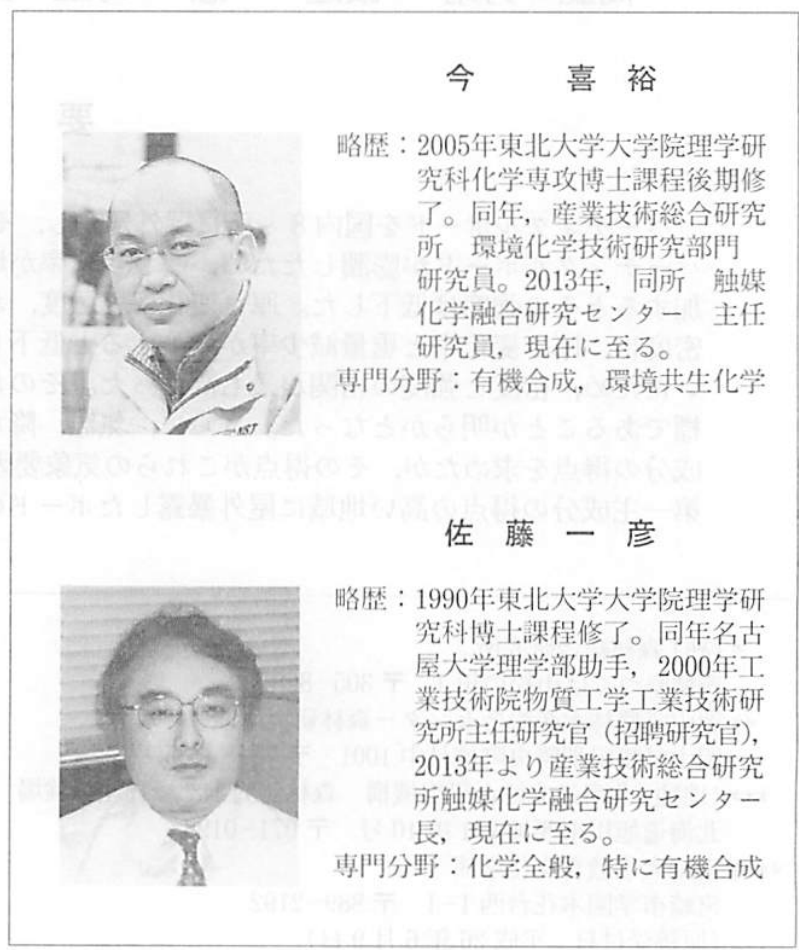


従来法:エピクロルヒドリン法

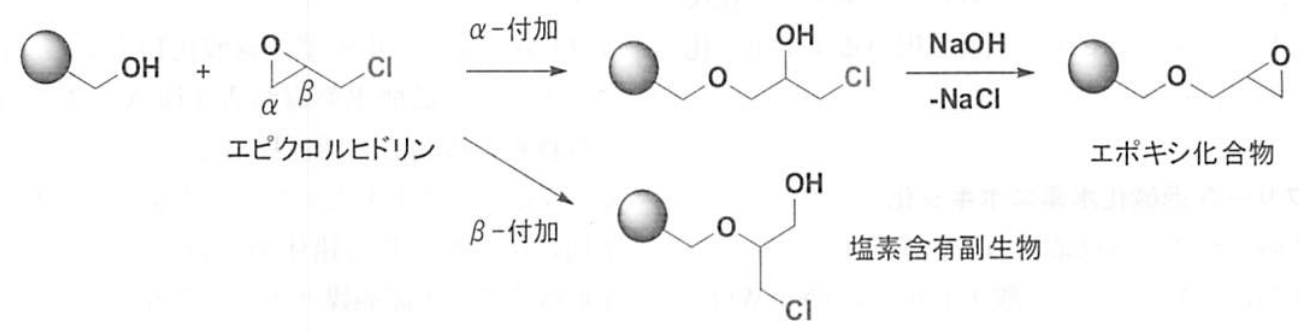

過酸化水素法

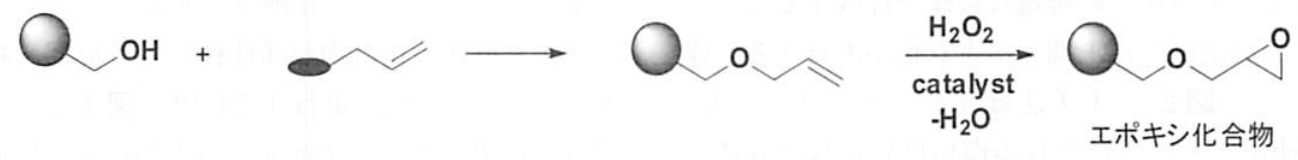

特長:塩素を含有する副生物が出ない

スキーム 1 従来法上過酸化水素酸化法

$\begin{array}{cl}\text { 過酸化水素 } & \text { 主な用途: } \\ \mathrm{H}_{2} \mathrm{O}_{2} & \text { 紙・パルプの漂白 } \\ \text { 排水処理、半導体洗浄 } \\ \text { 年産 約20万トン } & \text { 殺菌、消毒 }\end{array}$

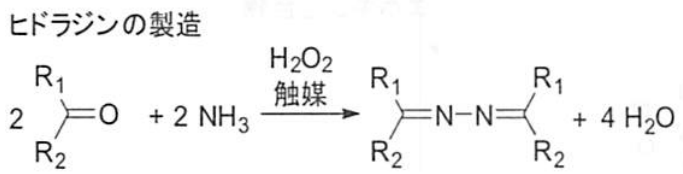

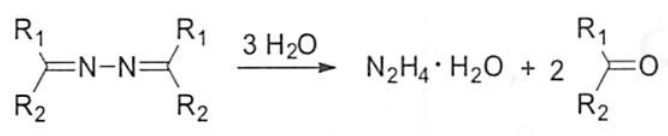

カテコール/ヒドロキノン併産

$\underset{-\mathrm{H}_{2} \mathrm{O}}{\stackrel{\mathrm{h}_{2} \mathrm{O}_{2}}{\mathrm{OH}}}$

オキシムの製造

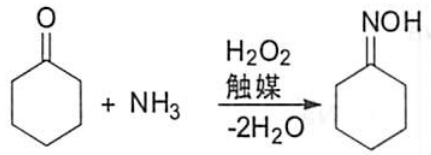

プロピレンオキシドの製造

$\mathrm{H}_{2} \mathrm{O}_{2}$

$\stackrel{\text { 触媒 }}{\longrightarrow} \mathrm{O}+\mathrm{H}_{2} \mathrm{O}$

図 1 過酸化水素と現在工業化されている例

である一方, 塩素含有副生物が製品に混入するという課題 あ持つ。

過酸化水素は酸化反応後に副生する廃较物が水のみであ
り，環境低負荷な酸化剤として知られている。過酸化水素 を酸化剂に用いる塩素フリーエポキシ化技術が確立できれ ば, 従来法を革新しインパクトが大きい（スキーム 1$)$ 。 過酸化水素は国内出荷量 20 万トン/年前後で製造されて おり，主な用途は紙・パルプの漂白，排水処理，半導体洗 浄, 殺菌, 消毒である ${ }^{6)}$ (図 1)。化学品製造に用いられて いる例としては, 三菱ガス化学 (㨆のヒドラジン製造, 宇 部興産(珠のカテコール/ヒドロキノン併産法, 住友化学 (株) のオキシム製造, BASF または夕゙ウ・ケミカルのプロピ レンオキシド製造などが知られている。しかし，精密化学 品に分類される複雑な構造を持つオレフィンを原料にして, 酸化反応によりエポキシ化する触媒的過酸化水素酸化法は, 現象として学術的に活発に研究されている一方, 実用的製 造法として使用された例はほとんどない。高選択的かつ高 効率な反応であり且つ，コストやスケールアップを考慮し た実用プロセスの開発は極めて難易度が高い。以下，過酸 化水素酸化技術の歴史とメカニズムの紹介, さらに現在試 みられている実用プロセスに向けた触媒開発の動向を紹介 する。

\section{2 触媒開発の歴史}

過酸化水素によるエポキシ化反応を促進する触媒技術の, 現象としての発見は 50 年以上前に遡る。比較的安価な夕 ングステン触媒を用いる方法としては, 1959 年に Payne とWilliams が $\alpha, \beta$-不飽和カルボン酸のエポキシ化反応 を7)，1983 年にはVenturello らがタングステン酸塩，ホ スホン酸, および 4 級アンモニウム塩からなる三元系触媒 を ${ }^{8)}, 1988$ 年には石井らが種々の基質について高効率エポ キシ化反応をそれぞれ報告している ${ }^{9)}$ 。なお, 触媒に用い 
る金属を限定しなければ，種々の高効率な反応が知られて おり，例えば，モリブデンやレニウムによるエポキシ化反 応, 不斉エポキシ化反応, ゼオライトを用いるエポキシ化 反応が報告されている1,10)。

\section{3 塩素フリーな過酸化水素エポキシ化}

1996 年, 佐藤, 野依らは反応性の低い末端オレフィンの エポキシ化反応に, タングステン酸ナトリウム $\left(\mathrm{Na}_{2} \mathrm{WO}_{4}\right)$ の他, メチル (トリオクチル) アンモニウム硫酸水素塩 $\left(\left[\mathrm{CH}_{3}\left(n-\mathrm{C}_{8} \mathrm{H}_{17}\right)_{3} \mathrm{~N}\right] \mathrm{HSO}_{4}\right.$ : 以下, $\left.\mathrm{QHSO}_{4}\right)$ とアミノメ チルホスホン酸 $\left(\mathrm{NH}_{2} \mathrm{CH}_{2} \mathrm{PO}_{3} \mathrm{H}_{2}\right.$ : 以下, AMPA) を組み 合わせることで，あらかじめ複雑な触媒を作成することな く, 高効率かつ高選択的に末端エポキシ化が進行する触媒 系を発見した ${ }^{11}$ （図 2)。本手法は「八ロゲンフリー」, 「有機溶媒不使用」といった今日の環境低負荷な合成法に 必ず使用されるキーワードを，実際の合成法開発と組み合 わせて提唱した最初の報告と屯言われている。反応のメカ
ニズムを図 2 に示す3b)。

タングステン酸ナトリウムと過酸化水素が作用し, W$\mathrm{O}$ - O からなる三角形型の過酸化物を生じ（活性種 A), アンモニウム硫酸水素塩が活性種 $\mathrm{A}$ と対を成すことによ り有機相に移動し(活性種 B), エポキシ化反応が進行す る。反応後, 酸素を失ったタングステン錯体（錯体 C）は, 水層に戻ったのち（錯体 D）再度活性化されて活性種 A を形成する。上記触媒サイクルを繰り返してエポキシ化合 物が製造される。なお, 活性種の構造は, ここではタング ステンの単核錯体の形に省略して記載しているが，実際は より複雑である。タングステンが 2 個, 4 個, あるいはよ り多くのタングステンが酸素, 水素, リンと組み合さった クラスター状の化合物が活性種として提案されている ${ }^{12)}$ 。 また，エポキシ化が進行する段階（図2で［］内に示した 部分）に関しては，プロトンの添加による促進や $\mathrm{pH}$ の調 整, AMPAなどホスホン酸のタングステン活性種への配 位など種々な要素が絡み合っており, 現在む反応機構の解

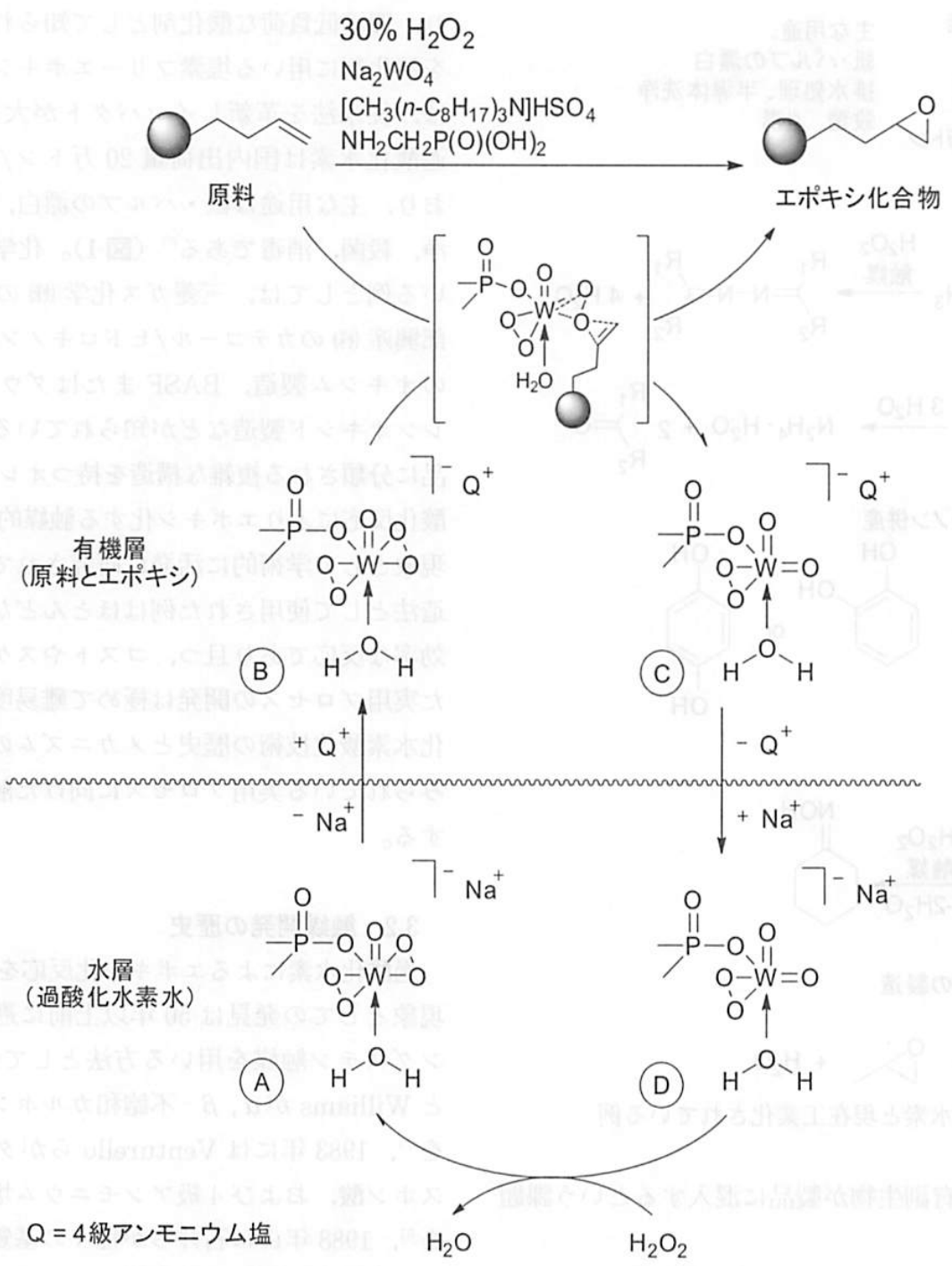

図 2 過酸化水素によるハロゲンフリーエポキシ化技術 
明が継続されている7.13)。

\section{4 実用化プロセスに向けた展開}

過酸化水素を用いて，エポキシ骨格を含む精密化学品を 製造する試みが近年活発に行われている。ここでは，過酸 化水素法により，テルペンにエポキシを導入した例と，封 止材の材料として有用なグリシジルエーテルを合成した例 の, 二例を示す。

テルペンは松やにを蒸留した際に得られるテレビン油と しても知られ，主に炭素数 $5,10 ， 15$ の直鎖状や環状の有 機化合物が知られている。テルペンをエポキシ化して生成 するテルペンオキシドは高機能な精密化学品としての利用 が期待されている ${ }^{14)}$ 。従来，テルペンオキシドの工業的な 製造法として，過酢酸を酸化剂に用いる方法が知られてい るが ${ }^{15)}$, 過酢酸法は過酢酸の爆発性が高いうえ, 反応後 に大量の酢酸を処理し，有機溶剤を大量使用する必要があ るなど，環境負荷の高い製造法である。環境低負荷である と共に, より安全, 安定, 高効率に製造する方法が切望さ れている。

有機溶媒不在下, 既知のタングステン触媒系を用いてテ ルペンの過酸化水素酸化を行った例が知られているが，同 時に共存する酸性の水によって生成したテルペンオキシド が加水分解し, 狙いとするエポキシ化合物は全く得られな (16)。著者らは, 経済産業省および NEDO の支援のむと, 荒川化学工業 (株) と共同研究を行い，テルペンの主成分と して知られる $\alpha$-ピネンを高効率かつ高選択的にエポキシ 化する新規触媒を開発した ${ }^{17)}$ 。従来のタングステン触媒 系による過酸化水素酸化反応を再度詳細に検討したところ， 生成する $\alpha$-ピネンオキシドを加水分解させる主要因が, $90^{\circ} \mathrm{C}$ の応温度であることを突き止めた。よりマイルドな

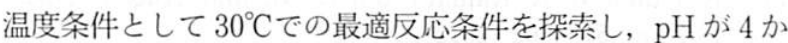
ら 6 程度の弱酸性条件下でフェニルホスホン酸 $\left(\mathrm{PhPO}_{3} \mathrm{H}_{2}\right)$ を助触媒に使用することにより， $\alpha$ ーピネンオキシドが収 率 $87 \%$ で得られる触媒系を開発した ${ }^{18)}$ 。

さらに，スケールアップに対応し，ょり安全性を高めた 触媒の開発を行い, 前記触媒系を改良し, 硫酸ナトリウム $\left(\mathrm{Na}_{2} \mathrm{SO}_{4}\right)$ を添加することで, $\alpha$-ピネンオキシドを数百 グラム/バッチスケールで製造可能な触媒の目途をつけた。 ここで開発したプロセスは，1）爆発性のない35\%以下の 濃度の過酸化水素水を用いる，2）有機溶媒を使用せず, $\alpha$-ピネンと過酸化水素水の直接接触により反応させる,

3）生成する $\alpha$-ピネンオキシドは一切分解せず，精製操 作が容易，4）塩素フリー，5）反応温度が 20 から $40^{\circ} \mathrm{C}$ 程 度で, 制御し易く省エネルギー, など実用化に展開可能な 要素を多数含んでいる ${ }^{17)}$ 。本開発技術は図 3 に示すように, $\alpha$-ピネンに限らず，種々のテルペンのエポキシ化に対応 することができ，それぞれ高収率でエポキシ化合物を与え

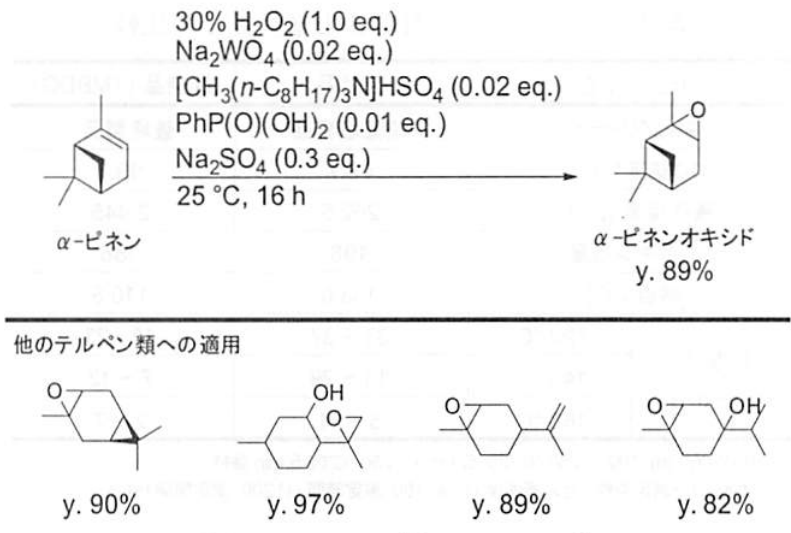

図 3 テルペン類のエポキシ化

表 1 アリルフェニルエーテルの塩素フリーエポキシ化

\begin{tabular}{l|c|c|c|c|c}
\hline \multicolumn{6}{c}{$\begin{array}{c}\mathrm{H}_{2} \mathrm{O} \\
\text { catalyst }\end{array}$} \\
\hline $\mathrm{WO}_{4}$ & $\mathrm{AMPA}$ & $\mathrm{QHSO}_{4}$ & 70 & 52 & 1 \\
\hline $\mathrm{NO}_{4}$ & $\mathrm{PhPO}_{3} \mathrm{H}_{2}$ & $\mathrm{CH}_{3}\left(n-\mathrm{C}_{8} \mathrm{H}_{17}\right)_{2} \mathrm{~N}$ & 50 & 64 & 69 \\
\hline
\end{tabular}

る。

次に, 経済産業省および NEDO の支援のもと, 昭和電 工 (踭) と共同開発した 3,3 ',5,5'-テトラメチルビフェニル4,4'-ジオールジグリシジルエーテル（TMBDG）の製造 方法について紹介する。モデル化合物としてアリルフェニ ルエーテルを選択し，触媒開発を行った結果を表 1 に示す。 まず, 従来最むエポキシ化反応に活性があるとされる $\mathrm{Na}_{2} \mathrm{WO}_{4}, \mathrm{AMPA}, \mathrm{QHSO}_{4}$ を組み合わせた触媒系で検討 したが ${ }^{16)}$ ，テルペンの場合と同様に生成するエポキシの 加水分解により，原料の反応率は $52 \%$, 選択率は $1 \%$ で あった。反応活性を保ちつつ, 加水分解を抑制する反応条 件を探索した結果, $\mathrm{Na}_{2} \mathrm{WO}_{4}$, タングステン酸 $\left(\mathrm{H}_{2} \mathrm{WO}_{4}\right)$, $\mathrm{PhPO}_{3} \mathrm{H}_{2}$, メチルジオクチルアミン $\left(\mathrm{CH}_{3}\left(n-\mathrm{C}_{8} \mathrm{H}_{17}\right)_{2} \mathrm{~N}\right)$ から成る触媒系を採用すると, 反応時間 1 時間でエポキシ 化合物が $69 \%$ の選択率で得られることを確認した ${ }^{19)}$ 。開 発した製造法を元に，触媒の改良を行い，最終的に TMB DG の塩素フリ一製造に成功した。得られた製品のデータ を表 2 に示す。GC 純度 $94 \%$, エポキシ当量は 186 であ

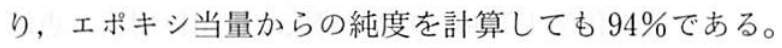
他社品（前述のエピクロルヒドリン法により合成）に比較 して, 過酸化水素法では融点や各温度での粘度について, ほとんど差がみられなかった。また, 検出塩素濃度（イオ ンクロマト分析）はおよそ $2 \mathrm{ppm}$ 程度であるため, 数百 ppmのオーダーで塩素を混入している他社製品に比べ大 幅に含有塩素量が低減されているといえる。アリル体構造 に由来して製品粘度も低く，高フィラー充填が可能である。 
表 2 塩素フリー TMBDG と他社品との比較

\begin{tabular}{|c|c|c|c|}
\hline \multicolumn{2}{|c|}{ サンプル名 } & 他社品 & 開発品 (TMBDG) \\
\hline \multicolumn{2}{|c|}{ 製品グレード } & 超低塩素品 & 最終製品 \\
\hline \multicolumn{2}{|c|}{ GC純度 ${ }^{\star 1}(\%)$} & 98.7 & 93.7 \\
\hline \multicolumn{2}{|c|}{ 残存塩素 (ppm) } & 262.5 & 2.445 \\
\hline \multicolumn{2}{|c|}{ エポキシ当量 } & 198 & 186 \\
\hline \multicolumn{2}{|c|}{ 融点 $\left({ }^{\circ} \mathrm{C}\right)$} & 103.0 & 110.8 \\
\hline \multirow{3}{*}{$\begin{array}{l}\text { 粘度 } \star 2 \\
(\mathrm{mPa} \cdot \mathrm{S})\end{array}$} & $120^{\circ} \mathrm{C}$ & $33 \sim 37$ & $18 \sim 23$ \\
\hline & $140^{\circ} \mathrm{C}$ & $13 \sim 29$ & $7 \sim 12$ \\
\hline & $160^{\circ} \mathrm{C}$ & $5 \sim 11$ & $2 \sim 7$ \\
\hline
\end{tabular}

${ }^{1} \mathrm{DB}-W A X(2 \mathrm{~m}), 100 \rightarrow 250^{\circ} \mathrm{C}\left(20^{\circ} \mathrm{C} / \mathrm{min}\right.$.), $250^{\circ} \mathrm{C}$ - $2.5 \mathrm{~min}$. 保持

-2レオメーター測定条件 : せん断速度 (1/s) 100, 測定時間 (s) 200, 㵋定間槅 (s) 2

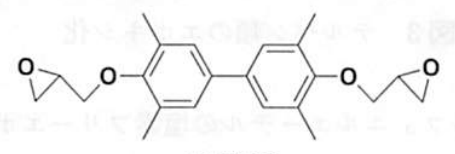

TMBDG

塩素フリーな過酸化水素エポキシ化技術の開発により, 従 来品と同等の取り扱いやすさと粘度を保持したまま，塩素 含有量だけが圧倒的に少ない製品の開発に成功した。

\section{4. おわりに}

本稿では, 八ロゲンフリーなエポキシ化合物の製造方法 として, 過酸化水素を用いるオレフィンからエポキシ化合 物への酸化反応について紹介した。基質に応じて最適な触 媒を設計することにより，高効率かつ高選択的に，目的と するエポキシ化合物を得ることが出来る。従来法とは異な り，八ロゲンフリー，有機溶媒の使用量を極小化，副生廃 棄物は水のみと，環境調和性に優れている。また，温和な 条件下で安価な触媒により安全かつ高効率に反応が進行す ることから，産業競争力の高い手法ともいえる。

ハロゲン，特に塩素フリーな条件で製造されたエポキシ 化合物は, 絶縁性能が向上する傾向にあり, 種々の化学品 に展開できると期待されている ${ }^{19)}$ 。筆者らは, 光学用途と して,ソルダーレジスト，封止材や次世代接着剤を見据え た製造方法の開発に着手している。今後, 益々過酸化水素 酸化技術を用いて製造されたハロゲンフリー製品が増えて ゆくと期待される。

\section{謝辞}

本原稿の作成にあたり，過酸化水素酸化技術の共同研究 を行った荒川化学工業 (侏) の内匠清氏，笹川巨樹氏，恵崎 陽一郎氏および昭和電工 (侏) の内田博氏，藤田俊雄氏，石 橋圭孝氏に厚くお礼申し上げます。また，当時産総研で研
究開発に携わってくれた千代健文氏, 小野豊氏, 蜂谷宝人 氏に厚く御礼申し上げます。なお，本発表成果の一部は, 経済産業省およびNEDO「革新的酸化プロセス基盤技術 開発」プロジェクトの支援を受けて行われました。

\section{文献}

1) 内田博, 日本接着学会誌, 47, 187 (2011).

2）規格として例えば、）IEC（国際電気標準会議）61249-2-21; b）米国 IPC（米国電子回路工業協会）4101B がある。

3) a) Y.Kon, T. Chishiro, H. Uchida, K. Sato and H. Shimada, J. Jpn. Petrol. Inst., 55, 277 (2012).

b) R. Noyori, M. Aoki and K. Sato, Chem. Commun., 1977 (2003).

4) 内田博, ペトロテック， 34, 101 (2011).

5）国内規格では, JPCA（社団法人 日本プリント回路工業会） の JPCA-ES01 が基板用として知られ，はんだに関しては この後改訂版（ET-7304など）が出されている。

6) a) 今喜裕, 佐藤一彦, 化学々工業, 65, 864 (2012).

b) 浜口高嘉, ファインケミカル, 35(3), 9 (2006).

7) G. B. Payne and P. H. Williams, J. Org. Chem., 24, 54 (1959).

8) C. Venturello, E. Alneri and M. Ricci, J. Org. Chem., 48, 3831 (1983).

9) Y. Ishii, K. Yamawaki, T. Ura, H. Yamada, T. Yoshida and M. Ogawa, J. Org. Chem., 53, 3587 (1988).

10）例えば, a) O. Bortolini, F. Di Furia, G. Modena and R. Seraglia, J. Org. Chem., 50, 2688 (1985).

b) W.A.Hermann, R.W. Fischer and D.W. Marz, Angew. Chem. Int. Ed., 30, 1638 (1991).

c) K. Matsumoto, B.Saito and T. Katsuki, Chem Commun., 3619 (2007); d) P. Wu, Y. Lin, M. He and T. Tatsumi, J. Catal., 228, 183 (2004).など。

11) K.Sato, M.Aoki, M. Ogawa, T. Hashimoto and R. Noyori, J. Org. Chem., 61, 8310 (1996).

12) a) C. Venturello, R. D'aloisio, J. C. J. Bart and M. Ricci, J. Mol. Catal., 32, 107 (1985).

b) C. Venturello and R. D'aloisio, J. Org. Chem., 53, 1553 (1988).

13) R. Ishimoto, K. Kamata and N. Mizuno, Angew. Chem. Int. Ed., 51, 4662 (2012).

14) a) A. Corma, S. Iborra and A. Velty, Chem. Rev., 107, 2411 (2007).

b) J. L. Bicas, A. P. Dionísio and G. M. Pastore, Chem. Rev., 109, 4518 (2009).

c) K. A. D. Swift, Top. Catal., 27, 143 (2004).

15）特開 2002-80557など。

16) K. Sato, M. Aoki, M. Ogawa, T. Hashimoto, D. Penyella, and R. Noyori, Bull. Chem. Soc. Jpn., 70, 905 (1997).

17) H. Hachiya, Y. Kon, Y. Ono, K. Takumi, N. Sasagawa, Y. Ezaki and K. Sato, Synlett, 2819 (2011).

18) Y. Kon, H. Hachiya, Y. Ono, T. Matsumoto and K. Sato, Synthesis, 1092 (2011).

19）今喜裕, 内田博, 佐藤一彦, 機能材料, 33, 40 (2013). 